\title{
15. Scientific Control Over Dual-Use Research: Prospects for Self-Regulation
}

\author{
David B. Resnik
}

\section{Introduction}

In the past decade, scientists, policymakers, ethicists and citizens have become increasingly aware that scientific research that promotes public health and safety has the potential to be used for terrorist, criminal or other malevolent purposes. ${ }^{1}$ The phrase 'dual-use research' refers to research that may have beneficial as well as detrimental consequences. The National Science Advisory Board for Biosecurity (NSABB), a US Government committee that provides advice to researchers and federal agencies, has defined 'dual-use research of concern' as 'research that, based on current understanding, can be reasonably anticipated to provide knowledge, products, or technologies that could be directly misapplied by others to pose a threat to public health and safety, agricultural crops and other plants, animals, the environment or materiel'.$^{2}$ Examples of published research that has raised dual-use issues include research on a mousepox virus that could be used to enhance the virulence of the human smallpox virus, ${ }^{3}$ a study showing how to manufacture a polio virus from available sequence data

\footnotetext{
1 Atlas, R. 2002, 'National security and the biological research community', Science, vol. 298, pp. 7534; Atlas, R. and Dando, M. 2006, 'The dual-use dilemma for the life sciences: perspectives, conundrums, and global solutions', Biosecurity and Bioterrorism, vol. 4, pp. 276-86; National Science Advisory Board for Biosecurity (NSABB) 2007, Proposed Framework for the Oversight of Dual Use Life Sciences Research: Strategies for Minimizing the Potential Misuse of Research Information, National Science Advisory Board for Biosecurity, Bethesda, Md, <http://oba.od.nih.gov/biosecurity/pdf/Framework\%20for\%20transmittal\%200807_Sept07. pdf $>$ (viewed 30 December 2011); Selgelid, M. 2007, 'A tale of two studies; ethics, bioterrorism, and the censorship of science', Hastings Center Report, vol. 37, no. 3, pp. 35-43; Resnik, D. B. and Shamoo, A. S. 2005, 'Bioterrorism and the responsible conduct of biomedical research', Drug Development Research, vol. 63, pp. 121-33; Selgelid, M. 2009, 'Governance of dual use research: an ethical dilemma', Bulletin of the World Health Organization, vol. 87, pp. 720-3; National Research Council 2004, Biotechnology Research in the Age of Terrorism, The National Academies Press, Washington, DC; National Research Council 2006, Globalization, Biosecurity and the Future of the Life Sciences, The National Academies Press, Washington, DC; Resnik, D. B. 2010, 'Can scientists regulate the publication of dual use research?' Studies in Ethics, Law, and Technology, vol. 4, no. 1, article 6, <http://www.bepress.com/selt/vol4/iss1/art6> (viewed 30 December 2011).

2 NSABB, op. cit.

3 Jackson, R., Ramsay, A., Christensen, C., Beaton, S. and Hall, D. 2001, 'Expression of mouse interleukin-4 by a recombinant ectromelia virus suppresses cytolytic lymphocyte responses and overcomes genetic resistance to mousepox', Journal of Virology, vol. 75, pp. 1205-10.
} 
and mail-order supplies, ${ }^{4}$ a study on the genetics of human smallpox virus that could be used to develop a strain of Vaccinia (the virus used in smallpox vaccine) that would overcome the immune system's natural defences, ${ }^{5}$ a paper describing how a terrorist could poison the US milk supply with botulinum toxin, ${ }^{6}$ and a paper demonstrating how to reconstruct the 1918 Spanish influenza virus from published sequence data. ${ }^{7}$

Preventing the use of scientific research for malevolent purposes raises dilemmas for ethics and public policy. Although most of these issues have existed in some form or another since the dawn of science, the globalisation of scientific research, advances in biotechnology and the spectre of bioterrorism create problems for bioscientists and other researchers that are complex, difficult and urgent. ${ }^{8}$ The fundamental dilemma related to dual-use research is how to protect society from harm without unduly hampering the advancement of science. ${ }^{9}$ While some restrictions on research are widely recognised as necessary to prevent the misuse of science, administrative, legal and bureaucratic oversight of research can hinder collaboration, the sharing of data and materials, and publication. ${ }^{10}$

Policymakers have explored two forms of oversight of dual-use research: governmental control and self-regulation. ${ }^{11}$ Government oversight mechanisms that have been used or proposed include ${ }^{12}$

- regulations, such as the Patriot Act, that control access to and transfer and storage of dangerous biological, chemical or radiological materials ${ }^{13}$

- laws related to the transfer of technology across national borders ${ }^{14}$

\footnotetext{
4 Cello, J., Paul, A. and Wimmer, E. 2002, 'Chemical synthesis of poliovirus cDNA: generation of infectious virus in the absence of natural template', Science, vol. 297, pp. 1016-18.

5 Rosengard, A, Liu, Y., Nie, Z. and Jimenez, R. 2002, 'Variola virus immune evasion design: expression of a highly efficient inhibitor of human complement', Proceedings of the National Academy of Sciences, vol. 99, pp. 8808-13.

6 Wein, L. and Liu, Y. 2005, 'Analyzing a bioterror attack on the food supply: the case of botulinum toxin in milk', Proceedings of the National Academy of Sciences, vol. 102, pp. 9984-9.

7 Tumpey, T. M., Basler, C. F., Aguilar, P. V., Zeng, H., Solórzano, A., Swayne, D. E., Cox, N. J., Katz, J. M., Taubenberger, J. K., Palese, P. and García-Sastre, A. 2005, 'Characterization of the reconstructed 1918 Spanish influenza pandemic virus', Science, vol. 310, pp. 77-80.

8 Atlas and Dando, op. cit.

9 Miller, S. and Selgelid, M. 2007, 'Ethical and philosophical consideration of the dual-use dilemma in the biological sciences', Science and Engineering Ethics, vol. 13, pp. 523-80.

10 Ibid.; Atlas and Dando, op. cit.

11 Miller and Selgelid, op. cit.; Atlas and Dando, op. cit.

12 Miller and Selgelid, op. cit.

13 Malakoff, D. 2002, 'Biological agents: new U.S. rules set the stage for tighter security, oversight', Science, vol. 298, p. 2304; Bhattacharjee, Y. 2010, 'Biosecurity: new biosecurity rules to target the riskiest pathogens', Science, vol. 329 , pp. 264-5.

14 National Research Council, 2006, op. cit.
} 
- classification of government-sponsored research that could threaten national security if disclosed ${ }^{15}$

- restrictions on government funding of research with potential dual-use implications $^{16}$

- restrictions on immigration of scientists with questionable backgrounds

- censorship of non-classified research that poses a threat to national security. ${ }^{17}$

Self-regulation by the scientific community might include ${ }^{18}$

- control over the dissemination of materials and technology by researchers and their institutions ${ }^{19}$

- review of research by committees charged with overseeing research ${ }^{20}$

- education and training in responsibilities related to dual-use research ${ }^{21}$

- development of professional ethics codes and institutional policies that address dual-use research ${ }^{22}$

- journal review of dual-use research. ${ }^{23}$

There is currently a vigorous debate over whether government oversight, selfregulation by the scientific community or some combination is the best way to control dual-use research. ${ }^{24}$ The main argument for government regulation is that self-regulation by the scientific community has significant limitations and is often ineffective. ${ }^{25}$ There is some justification for this view. First, scientists (and non-governmental research organisations) lack the legal authority to adequately control some types of research. For example, scientists do not have the authority to classify information, restrict access to dangerous materials or prevent the transfer of technologies across national borders. ${ }^{26}$ Second, scientists often lack the expertise or resources needed to make decisions pertaining to dual-use research. ${ }^{27}$ For example, scientists reviewing dual-use research for

\footnotetext{
15 Resnik, D. B. 2009, Playing Politics with Science, Oxford University Press, New York; National Research Council, 2004, op. cit.

16 Resnik and Shamoo, op. cit.

17 van Aken, J. 2006, 'When risk outweighs benefit: dual-use research needs a scientifically sound riskbenefit analysis and legally binding biosecurity measures', EMBO Reports, vol. 7(SI), pp. S10-13; Miller and Selgelid, op. cit.

18 NSABB, op. cit.

19 Atlas and Dando, op. cit.

20 NSABB, op. cit.

21 Somerville, M. and Atlas, R. 2005, 'Ethics: a weapon to counter bioterrorism', Science, vol. 307, pp. $1881-2$.

22 Rappert, B. 2004, 'Responsibility in the life sciences: assessing the role of professional codes', Biosecurity and Bioterrorism, vol. 2, pp. 164-74.

23 van Aken, J. and Hunger, I. 2009, 'Biosecurity policies at international life science journals', Biosecurity and Bioterrorism, vol. 7, pp. 61-71.

24 Miller and Selgelid, op. cit.; van Aken, op. cit.; Resnik, 2010, op. cit.; Atlas and Dando, op. cit.

25 Miller and Selgelid, op. cit.; Selgelid, op. cit.; van Aken, op. cit.

26 National Research Council, 2006, op. cit.

27 Miller and Selgelid, op. cit.
} 
an institutional biosafety committee (IBC) may not have access to information related to national security interests or threats. Third, scientists have a vested interest in promoting research that may conflict with their social responsibility to prevent harmful uses of research. ${ }^{28}$ Journals may be more interested in publishing research that will generate interest and discussion than in preventing the dissemination of information that could threaten society.

The argument against government regulation is that it may pose a significant threat to the advancement of science. Freedom of inquiry, association and expression are essential to scientific research. ${ }^{29}$ Government restrictions on science and technology can undermine collaboration, creativity, criticism, publication and sharing of data, materials and methods. Especially worrisome are restrictions on publication - the lifeblood of science. ${ }^{30}$ Since the 1980s, the official policy of many governments, including the US Government, has been not to interfere with the publication of non-classified scientific research; ${ }^{31}$ however, concerns about dual-use research have led some commentators to question the wisdom of this policy. ${ }^{32}$ The NSABB has reviewed papers with dual-use implications, but its opinions are purely advisory and do not determine publication decisions. ${ }^{33}$ Government restrictions on access to research materials can also have negative impacts on science, since they can interfere with collaborations among researchers, especially international ones. In the United States, scientists must submit to background checks in order to access dangerous biological materials classified as select agents, ${ }^{34}$ which has generated concerns about the potential for racial or ethnic discrimination. ${ }^{35}$ Any type of government restriction on scientific research also raises the possibility of politically motivated interference in the scientific process. ${ }^{36}$

I will not discuss or assess government oversight of dual-use research in depth, since the aim of this chapter is to examine the prospects for self-regulation of dual-use research; however, the conclusions reached in this chapter may have implications for government oversight, since one of the main arguments for government involvement is that attempts at self-regulation are likely to be ineffective. This chapter will describe the different mechanisms that scientists might use to control dual-use research and assess the potential effectiveness

8 Ibid.

29 Resnik, 2009, op. cit.

30 Journal Editors and Authors Group 2003, 'Uncensored exchange of scientific results', Proceedings of the

National Academy of Sciences, vol. 100, p. 1464.

31 Resnik, 2009, op. cit.

32 Miller and Selgelid, op. cit.

33 NSABB, op. cit.

34 Bhattacharjee, op. cit.

35 Resnik and Shamoo, op. cit.

36 Resnik, 2009, op. cit. 
of these mechanisms, including: control over transfer of materials, review by institutional committees, education and training, professional codes, and journal policies.

\section{Control over the transfer of materials}

Every day, scientists send materials and technologies, such as reagents, cell lines, pathogens and laboratory animals, to other scientists. Most institutions sign a material transfer agreement (MTA) when they transfer materials. MTAs state the terms and conditions for using such materials, and can be enforced through contract law. Although laws and regulations govern the transfer of some types of materials, such as select biological agents and radioactive substances, they do not cover all the types of materials that might be used for harmful purposes, as some materials might not be deemed dangerous enough to warrant regulations, and other dangerous materials might not yet have been identified (as such). For example, when investigators published research on the 1918 Spanish influenza virus, this pathogen was not on the list of select agents, and it was not until later that the list was amended to cover this material. ${ }^{37}$

Scientists can play an important role in preventing the transfer of dangerous materials to individuals or organisations with reprehensible motives by attempting to determine whether the request for materials comes from a legitimate, respected researcher or whether it comes from a suspicious individual or organisation. They can ask for curriculum vitae, research protocol and other information necessary to verify the requestor's expertise, background and affiliations. If they have any doubts about the legitimacy of the request, they can delay the transfer until they are satisfied that the requestor is a responsible scientist, or they can consult institutional officials on how to proceed.

Whether scientific control over the transfer of materials and technologies will be an effective mechanism for preventing the use of these items for malevolent purposes remains to be seen. For this mechanism to be effective, investigators must first be aware of the dual-use implications of transferring materials and technologies. A survey of attitudes of US life scientists concerning dual-use research indicates that most are aware of biosecurity issues, although a majority considers the risk of a bioterror attack to be small. A small percentage of those surveyed indicated that they had refused to collaborate with some individuals due to biosecurity concerns. ${ }^{38}$ Although many scientists are aware of dual-use

37 National Select Agent Registry 2010, <http://www.selectagents.gov/Select\%20Agents\%20and\%20 Toxins\%20List.html> (viewed 30 December 2011).

38 Committee on Assessing Fundamental Attitudes of Life Scientists as Basis for Biosecurity Education 2009, A Survey of Attitudes and Actions on Dual Use Research in the Life Sciences: A Collaborative Effort of 
issues, education (discussed below) can help to raise awareness. Investigators must also be willing to invest some of their time and effort into verifying the legitimacy of individuals or organisations requesting materials or technologies. Investigators who have extensive responsibilities related to research, teaching or administration may feel that they do not have enough time to devote such attention to requests for materials and technologies. Educational sessions may be able to convince investigators of the importance of this issue.

\section{Review by institutional committees}

Several different institutional committees may have the opportunity to review research with dual-use implications. These committees can decide whether the research should be approved, disapproved or approved with additional oversight or restrictions to prevent harmful consequences. Most of the discussion thus far has focused on the role of IBCs in addressing the dual-use implications of research. IBCs are responsible for reviewing research involving hazardous biological materials, such as pathogens and toxins, as well as recombinant DNA research, including experiments to transfer genes to plants, animals and humans. ${ }^{39}$ IBCs are in charge of protecting researchers and the public from risks related to research on hazardous biological materials. IBCs include experts in microbiology, genetics, pathology, immunology and other disciplines with the requisite expertise. IBCs are a natural place for the review of research with dualuse implications, given their function and expertise. ${ }^{40}$ Institutional animal care and use committees (IACUCs) review research involving research on animals. The main function of IACUCs is to protect the welfare of laboratory animals, and to ensure that investigators are using methods that minimise pain, suffering and distress. ${ }^{41}$ Though IACUCS lack the mandate and expertise to review dual-use issues, they could refer any research that raises concerns to an IBC. Institutional review boards (IRBs) review research involving human subjects, and their main function is to protect the rights and welfare of individuals participating in research. IRBs, like IACUCs, lack the mandate or expertise to review dual-use issues, but they could make a referral to an IBC. ${ }^{42}$

the National Research Council and the American Association for the Advancement of Science, The National Academies Press, Washington, DC, < http://books.google.com/books/about/A_Survey_of_Attitudes_and_ Actions_on_Dua.html?id=2-MLru0bHkQC $>$ (viewed 30 December 2011).

39 Cornell University 2007, Institutional Biosafety Committee, <http://www.ibc.cornell.edu/ responsibilities $>$ (viewed 30 December 2011).

40 NSABB, op. cit.

41 Shamoo, A. S. and Resnik, D. B. 2009, Responsible Conduct of Research, 2nd edn, Oxford University Press, New York.

42 Resnik, D. B. 2010, 'Dual-use review and the IRB', Journal of Clinical Research Best Practices, vol. 6, no. $1,<$ http://www.firstclinical.com> (viewed 30 December 2011). 
Although these three committees have the ability to identify scientific research with dual-use implications, inevitably some research may fall through the cracks, such as biomedical research that does not involve dangerous pathogens or animal or human subjects; chemical research; and engineering research. For example, the study of how to infect the US milk supply with botulinum toxin would not have been reviewed by any IBC, IACUC or IRB. ${ }^{43}$ Because these committees may lack the expertise to assess the dual-use implications of research that falls within their purview, the NSABB has recommended that institutions consider appointing committees that focus on dual-use research. ${ }^{44}$ It is not known how many institutions have created such committees, although the National Institutes of Health (NIH) intramural program has a dual-use committee. ${ }^{45}$

Review of research by institutional committees is likely to be one of the most effective ways of preventing harms related to dual-use research. First, most institutions already have IBCs, IACUCs and IRBs or equivalent committees. Second, since these committees are accustomed to dealing with a variety of ethical, legal and social issues related to research, it will not come as a surprise to most committee members that they should be mindful of dual-use concerns. Third, these committees are likely to know how to access the appropriate institutional officials (for example, vice-president for research, compliance officer) for dealing with dual-use issues. Although institutional committees are well positioned to deal with dual-uses issues, it is not known how often these committees encounter research that raises dual-use concerns, whether they recognise the dual-use implications, or how they typically respond to these situations. More research is needed to get a better understanding of the effectiveness of institutional committees of dealing with dual-use issues.

\section{Education and training}

The NSABB ${ }^{46}$ and other commentators ${ }^{47}$ have recommended that investigators, students and trainees receive education concerning their responsibilities related to dual-use research. Education should cover topics pertaining to dual use, such as select agents, control of dangerous materials and the potential consequences of research and publication. Many funding organisations and institutions already require or support some type of education in responsible conduct of research (RCR) to promote scientific integrity. In the United States, the NIH and the National Science Foundation (NSF) mandate research ethics training 
requirements for students supported with grants funds. ${ }^{48}$ Education in RCR varies considerably. Some institutions require students to complete online modules in RCR, while others require attendance at classes, workshops or seminars. ${ }^{49}$ RCR education typically addresses fabrication, falsification, plagiarism, data management, conflict of interest, authorship, publication, mentoring and peer review, but this list could be expanded to include dual-use issues. It is not known how many institutions have conducted education and training in dual-use research, and more research is needed on this topic. In 2009, the NIH required that all intramural researchers and trainees receive education on their social responsibilities related to dual-use research. The educational materials developed by the NIH included an overview of dual-use research as well as several case studies. ${ }^{50}$

While education in dual-use issues is likely to play an important role in preventing the misuse of scientific research or materials, its effectiveness has been questioned. According to some studies, RCR education does not decrease the prevalence of negative behaviour, such as data falsification or plagiarism. ${ }^{51}$ Other studies suggest that RCR education can promote awareness of ethical issues and knowledge of ethical concepts, but does not influence attitudes or behaviour. ${ }^{52}$ Although there have been no published studies on the effectiveness of dual-use education and training, it is plausible to hypothesise that these efforts may have mixed results, given the scientific community's experiences with RCR education and training. A survey of life scientists indicates they support education and training initiatives that cover dual-use research; ${ }^{53}$ however, more research is needed on the effectiveness of dual-use education, and the effectiveness of different pedagogical techniques - for example, seminars, online training, and so on.

\footnotetext{
48 Shamoo and Resnik, op. cit.

49 Ibid.

50 Schwartz, op. cit.

51 Anderson, M. S., Horn, A. S., Risbey, K. R., Ronning, E. A., de Vries, R. and Martinson, B. C. 2007, 'What do mentoring and training in the responsible conduct of research have to do with scientists' misbehavior? Findings from a national survey of NIH-funded scientists', Academic Medicine, vol. 82, pp. 853-60.

52 Schmaling, K. B. and Blume, A. W. 2009, 'Ethics instruction increases graduate students' responsible conduct of research knowledge but not moral reasoning', Accountability in Research, vol. 16, pp. 268-83; Plemmons, D., Brody, S. and Kalichman, M. 2006, 'Student perceptions of the effectiveness of education in the responsible conduct of research', Science and Engineering Ethics, vol. 12, pp. 571-82; Powell, S., Allison, M. and Kalichman, M. 2007, 'Effectiveness of a responsible conduct of research course: a preliminary study', Science and Engineering Ethics, vol. 13, pp. 249-64.

53 Committee on Assessing Fundamental Attitudes of Life Scientists as Basis for Biosecurity Education, op. cit.
} 


\section{Professional codes}

The $\mathrm{NSABB}^{54}$ and other commentators ${ }^{55}$ have recommended that professional associations should develop codes of ethics (or conduct) to promote selfregulation of dual-use research. In response to the dual-use concerns that arose in 2001, the American Society for Microbiology (ASM) revised its code of ethics, which now includes the following paragraph:

ASM members are obligated to discourage any use of microbiology contrary to the welfare of humankind, including the use of microbes as biological weapons. Bioterrorism violates the fundamental principles upon which the Society was founded and is abhorrent to the ASM and its members. ASM members will call to the attention of the public or the appropriate authorities misuses of microbiology or of information derived from microbiology. ${ }^{56}$

Other professions with codes that address dual-use issues include the International Union of Biochemistry and Molecular Biology (IUBMB) ${ }^{57}$ and the American Medical Association (AMA). ${ }^{58}$ It is not known how many other professions have such codes but development thus far has been sparse. ${ }^{59}$ The NSABB has published some considerations for developing a code of conduct related to dual-use research in the life sciences, which address such topics as proposing, managing and conducting research; collaborations; public communications; and mentoring. ${ }^{60}$

The effectiveness of professional codes at promoting ethical conduct has been the subject of much debate. ${ }^{61}$ Some argue that professional codes are merely symbolic statements of values that have little effect on behaviour. Others argue that codes provide useful guidance for members of the profession and help promote public trust by defining standards of conduct; ${ }^{62}$ however, most professional codes lack enforcement mechanisms. Those that are the most effective are linked to professional licensure or certification, which can result

\footnotetext{
54 NSABB, op. cit.

55 Rappert, op. cit.

56 American Society for Microbiology (ASM) 2005, Code of Ethics, <http://www.asm.org/ccLibraryFiles/ FILENAME/000000001596/ASMCodeofEthics05.pdf> (viewed 30 December 2011).

57 International Union of Biochemistry and Molecular Biology (IUBMB) 2005, Code of Ethics, <http://www. babonline.org/bab/babcethics.pdf> (viewed 30 December 2011).

58 American Medical Association (AMA) 2004, Code of Medical Ethics, Opinion 2.078 - Guideline to Prevent Malevolent Use of Biomedical Research, <http://www.ama-assn.org/ama/pub/physician-resources/medicalethics/code-medical-ethics/opinion2078.shtml> (viewed 30 December 2011).

59 Rappert, B. 2007, 'Codes of conduct and biological weapons: an in-process assessment', Biosecurity and Bioterrorism, vol. 5, pp. 1-10.

60 NSABB, op. cit.

61 Rappert, 2007, op. cit.

62 Bayles, M. 1988, Professional Ethics, 2nd edn, Wadsworth, Belmont, Calif.
} 
in suspension of one's licence or disbarment for misbehaviour. For example, lawyers who violate ethical standards set by their bar association can have their licence to practise law revoked..$^{63}$ Since licensure by a professional association is not necessary to conduct many types of scientific research, scientific codes of ethics usually lack the coercive power to control behaviour. A microbiologist who violates the ASM code of ethics can still practise microbiology even if he is sanctioned by the organisation. Despite these limitations, many argue that scientific professional codes can still play an important role in guiding conduct, even if they lack coercive power. ${ }^{64}$

\section{Institutional policies}

The NSABB has also recommended that institutions develop policies addressing dual-use issues, complimenting existing RCR policies. ${ }^{65}$ Many scholars and commentators have argued that institutional policies, combined with education and training, can help promote ethical conduct in research; ${ }^{66}$ however, it is difficult to assess the effectiveness of institutional policies due to social, economic and cultural differences among institutions. Studies have shown that there is considerable variation in the content of some institutional ethics policies, such as conflict-of-interest and misconduct rules. ${ }^{67}$ In the United States, the content of institutional policies is largely driven by government mandates, such as $\mathrm{NIH}$ or NSF rules that require institutions to establish conflict-of-interest, misconduct, animal research and human subjects research policies as a condition of obtaining funding. ${ }^{68}$ Federal agencies could promote institutional policy development by requiring that funding recipients have dual-use policies; however, so far no federal agency has done so.

Institutional dual-use policies could play a key role in preventing the misuse of scientific work for malevolent purposes. Policies could address controlling, securing, transferring and accessing hazardous materials, as well as publishing research that could be readily used to cause significant harm to

63 Rotunda, R. 2007, Legal Ethics, 3rd edn, West Publishing, St Paul, Minn.

64 Shamoo and Resnik, op. cit.; Rappert, 2007, op. cit.

65 NSABB, op. cit.

66 Institute of Medicine 2002, Integrity in Scientific Research: Creating An Environment that Promotes Responsible Conduct, The National Academies Press, Washington, DC; Geller, G., Boyce, A., Ford, D. E. and Sugarman, J. 2010, 'Beyond "compliance": the role of institutional culture in promoting research integrity', Academic Medicine, vol. 85, pp. 1296-302.

67 Cho, M. K., Shohara, R., Schissel, A. and Rennie, D. 2000, 'Policies on faculty conflicts of interest at US universities', Journal of the American Medical Association, vol. 284, pp. 2203-28; McCrary, S. V., Anderson, C. B., Jakovljevic, J., Khan, T., McCullough, L. B., Wray, N. P. and Brody, B. A. 2000, 'A national survey of policies on disclosure of conflicts of interest in biomedical research', New England Journal of Medicine, vol. 343, pp. 1621-6; Lind, R. A. 2005, 'Evaluating research misconduct policies at major research universities: a pilot study', Accountability in Research, vol. 12, pp. 241-62.

68 Shamoo and Resnik, op. cit. 
public health, society, security or the environment. In theory, institutional policies could be more effective than professional codes, because institutional policies are enforceable. Scientists or students who violate university policies can be suspended, demoted, fired or dismissed. It is not known how many institutions have developed dual-use policies, but probably very few have, since universities usually do not develop ethical oversight mechanisms in the absence of legal or financial threats. ${ }^{69}$ Government action could spur the development of institutional policies.

\section{Journal policies}

Scientific journal dual-use review policies are another form of self-governance. Journals have been at the centre of the dual-use controversy, as several papers published by prominent journals have been controversial. For example, several members of the US Congress criticised journal editors for publishing the paper on how to manufacture a polio virus mentioned earlier. The US Department of Health and Human Services (DHHS) asked the editors of the Proceedings of the National Academy of Sciences (PNAS) not to publish the paper on contaminating the US milk supply, also mentioned earlier. ${ }^{70}$ The editors of PNAS met with DHHS representatives prior to publication to discuss the benefits and risks of public dissemination of the findings. The Department of Homeland Security (DHS) asked the NSABB to review the paper on reconstructing the 1918 pandemic influenza virus prior to publication in Science. Although the NSABB voted unanimously in favour of publication, the editor of Science publicly stated he would have ignored the NSABB's recommendations if had been against publication. ${ }^{71}$

Recently, the NSABB recommended that journals omit important details from research that used genetic-engineering techniques to create a mutated form of an avian flu virus, $\mathrm{A}(\mathrm{H} 5 \mathrm{N1})$, which could be transmitted between mammalian species, including humans. Key details would be available only to responsible scientists. Currently, the virus can only be transmitted from birds to other mammalian species, not between members of mammalian species. Six hundred people have contracted the virus since 1997, and more than half of them have died. The journals reviewing the research, Science and Nature, had not made a decision concerning publication as of the writing of this chapter. ${ }^{72}$

69 Ibid.

70 Resnik and Shamoo, op. cit.

71 Kennedy, D. 2005, 'Better never than late', Science, vol. 310, p. 195.

72 Grady, D. and Broad, W. 2011, 'Seeing terror risk, U.S. asks journals to cut flu study facts', The New York Times, 20 December 2011, p. Al. 
Journals began developing dual-use review policies in the early part of the twenty-first century, following the publication of several controversial papers. ${ }^{73}$ Some of the leading journals with dual-use review policies include Science, journals published by the Nature Publishing Group (NPG) - that is, Nature, Nature Biotechnology, and so on-and journals published by ASM. ${ }^{74}$ Review policies include an additional level of review for papers that raise dual-use concerns. Outside reviewers with expertise in national security, terrorism or other relevant subjects may be asked to assist with the review. The outcome of the review could include a recommendation to publish, to not publish or to publish with appropriate revisions, such as restrictions on access to key information. ${ }^{75}$ The NPG's dual-use policy provides that:

Nature journal editors may seek advice about submitted papers not only from technical reviewers but also on any aspect of a paper that raises concerns ... As in all publishing decisions, the ultimate decision whether to publish is the responsibility of the editor of the Nature journal concerned. The threat posed by bioweapons raises the unusual need to assess the balance of risk and benefit in publication. Editors are not necessarily well qualified to make such judgements unassisted, and so we reserve the right to take expert advice in cases where we believe that concerns may arise. We recognize the widespread view that openness in science helps to alert society to potential threats and to defend against them, and we anticipate that only very rarely (if at all) will the risks be perceived as outweighing the benefits of publishing a paper that has otherwise been deemed appropriate for a Nature journal. Nevertheless, we think it appropriate to consider such risks and to have a formal policy for dealing with them if need arises. The editorial staff of Nature journals maintains a network of advisers on biosecurity issues. All concerns on that score, including the commissioning of external advice, will be shared within an editorial monitoring group consisting of the Editor-in-Chief of Nature publications, the Executive Editor of the Nature research journals, the Chief Biological Sciences Editor of Nature, and the chief editor of the journal concerned. Once a decision has been reached, authors will be informed if biosecurity advice has informed that decision. ${ }^{76}$

73 Resnik, 2010, op. cit.

74 van Aken and Hunger 2009, op. cit.

75 Report of the NSABB Working Group on Journal Review Policies 2010, NSABB Board Meeting, 19 October 2010, <http://oba.od.nih.gov/oba/biosecurity/meetings/Oct2010/Journal_Review_Policies_Slides.pdf> (viewed 30 December 2011).

76 Nature Publishing Group (NPG) 2010, Biosecurity Policy, <http://www.nature.com/authors/editorial_ policies/biosecurity.html> (viewed 30 December 2011). 
There have been three published studies to date on the dual-use review policies of scientific journals. In 2009, van Aken and Hunger published a survey of 28 major life-science journals that regularly publish research that may raise biosecurity issues. They found that 25 per cent of these journals had dual-use review policies. ${ }^{77}$ In October 2010, a working group from the NSABB reported their findings at an NSABB board meeting. Members of the working group reported on their discussions with the editors of 18 high-impact life-science journals that had published dual-use review policies online. Members of the working group found that different models of dual-use review were in place, and that editors felt they needed additional guidance. ${ }^{78}$

Though these two studies provide some useful information about the dual-use policies of scientific journals, they do not provide systematic information about journal policy development because the sampling was focused (not random) and the sample sizes were small. To overcome these limitations, my colleagues and I conducted a larger survey of biomedical journals. We drew a random sample of 400 journals from the ISI Web of Knowledge Journal Citation Reports 2009 Edition. We eliminated journals that had little chance of reviewing dual-use research. We sent out an email survey to the editors and reminders after seven and 14 days if we did not receive a response. Of these, 155 journals responded to our survey (response rate 39 per cent). Only 7.7 per cent said they had a formal (written) dual-use policy; 72.8 per cent said they had had no experience with reviewing dual-use research in the past five years, 5.8 per cent indicated they had some experience, and 21.8 per cent did not give a definite answer to this question. We attempted to determine whether several variables were associated with having a dual-use policy. Belonging to the NPG was the most significant predictor of having a policy (positive association). Having experience with reviewing manuscripts with dual-use implications was also positively associated with having a policy. ${ }^{79}$

Our research indicates that less than 8 per cent of biomedical journals have a dual-use policy. This is much lower than the percentage reported by van Aken and Hunger. This is an important finding, since it shows that the scientific community has not made much progress in an important area of self-regulation. Another important finding is that most journals have not had any experience with reviewing research with dual-use implications. Indeed, some editors said they had not developed a policy because they saw no need for one, and others had not even heard of the term 'dual use'. Some editors said they were planning to develop a policy after they learned about our study. ${ }^{80}$

\footnotetext{
77 van Aken and Hunger, op. cit.

78 Report of the NSABB Working Group on Journal Review Policies, op. cit.

79 Resnik, D. B., Barner, D. D. and Dinse, G. E. 2011, 'Dual use policies of biomedical journals', Biosecurity and Bioterrorism, vol. 9, pp. 49-54.

80 Ibid.
} 


\section{Conclusion: Prospects for self-regulation}

So what are the prospects for self-regulation of dual-use research? It is difficult to say at this point, because there has been very little empirical research that addresses this question. While a survey of life scientists indicates that most are aware of biosecurity issues, research on biomedical journals indicates that only a small percentage has developed dual-use review policies. Also, very few professional associations have developed dual-use policies. We lack systematic data on other important aspects of self-regulation, such as institutional policies and oversight, and education and training efforts. Clearly, more research is needed to better understand how the scientific community is responding to the dual-use dilemma, and any conclusions drawn at this point about prospects for self-regulation should be viewed as tentative.

Looking to the past as a predictor of the prospects for self-regulation, we find that scientists have had some successes and some failures. One of the best examples of successful self-regulation would be the management of the risks related to recombinant DNA. In the early 1970s, scientists began to conduct experiments involving the transfer of DNA to micro-organisms. The public became gravely concerned about the threat of 'superbugs' escaping from the laboratory and causing a modern plague. The NIH responded to the public's anxiety by forming the Recombinant DNA Advisory Committee (RAC) in 1974 to oversee NIH-funded recombinant DNA research. Scientists who were at the forefront of recombinant DNA research met in Asilomar, California, in February 1975 to discuss the risks of their work and make some recommendations to protect laboratory workers, the public and the environment from biohazards. The recommendations included a number of different safety procedures, such as only using organisms that are unable to survive outside the laboratory, physical containment protocols and following good laboratory practices. The scientists also recommended a voluntary moratorium on experiments that were deemed too risky and said that work should move forward cautiously. ${ }^{81}$ In 1976, the RAC published its first set of guidelines for NIH-funded recombinant DNA research. Among the RAC's most important recommendations was that institutions establish biosafety committees to oversee recombinant DNA research. Although the RAC guidelines apply only to NIH research, scientists who are not funded by the NIH have also often followed the RAC's recommendations. ${ }^{82}$ While the government has played an important role in helping to promote responsible

\footnotetext{
81 Berg, P., Baltimore, D., Brenner, S., Roblin III, R. O. and Singer, M. F. 1975, 'Summary statement of the Asilomar Conference on Recombinant DNA Molecules', Proceedings of the National Academy of Sciences, vol. 72, pp. 1981-4.

82 Kimmelman, J. 2009, Gene Transfer and the Ethics of First-in-Human Research: Lost in Translation, Cambridge University Press, Cambridge.
} 
recombinant DNA research, scientists have taken it upon themselves to establish and follow safety standards. Although public anxieties about genetic engineering persist, the safety record of recombinant DNA research is excellent. ${ }^{83}$

An example of not-so-successful self-regulation would be research involving human subjects. Prior to World War II, there were no widely recognised ethical standards for research involving human subjects. Scientists and physicians appealed to their own sense of right and wrong in treating human beings used in research. ${ }^{84}$ In most cases, research was ethical and humane; however, there were many abuses involving risky procedures, experimentation without consent and the use of vulnerable populations, such as children, prisoners and mentally disabled adults, as research subjects. The worst of these abuses occurred in Germany under the Nazi regime, when scientists and physicians used concentration camp prisoners as research subjects. These experiments often produced severe pain and suffering and often resulted in death. Informed consent was out of the question. ${ }^{85}$ After the war ended, German physicians and scientists were tried for war crimes related to human experimentation. In 1947, the Nuremberg War Tribunals adopted the Nuremberg Code, the world's first ethical guidelines for research with human subjects, to use as a basis for trying physicians and scientists accused of war crimes. ${ }^{86}$ While the Nuremberg Code provided important guidance for researchers, it did not constitute government oversight because it established an ethical standard, not a legal one. The first steps towards government oversight of research with human subjects in the United States occurred in 1966, when the NIH adopted rules for research that it sponsors. In 1971, the Food and Drug Administration (FDA) adopted human subjects research rules. ${ }^{87}$

The US Government started to play a much more prominent role in the oversight of research with human subjects in the 1970s, when Congress held hearings on the Tuskegee syphilis study and other ethical abuses in research involving human subjects. The Tuskegee syphilis study, in which researchers investigated the natural course of untreated syphilis in black men, was funded by the Public Health Service and ran from 1932 to 1972. It included 399 patients with untreated syphilis and 400 controls. The subjects were not told that they were participating in a research study. They were told only that they were getting medical treatment for 'bad blood'. The investigators also took steps to prevent the syphilitic patients from receiving penicillin, an effective treatment, when it

83 Ibid.

84 Shamoo and Resnik, op. cit.

85 Ibid.

86 Nuremberg Code 1947, Directives for Human Experimentation, <http://ohsr.od.nih.gov/guidelines/

nuremberg.html > (viewed 30 December 2011).

87 Shamoo and Resnik, op. cit. 
became available in the $1940 s{ }^{88}$ In 1973, Congress responded to the abuses of human research subjects by passing the National Research Act (NRA), which established the National Commission for the Protection of Human Subjects in Biomedical and Behavioral Research to study the ethics of research with human subjects and authorised federal agencies to draft regulations. The national commission published its findings, known as the Belmont Report, in 1979, which provided the conceptual underpinning for a major revision of the federal research regulations in 1981, which have changed little in the past 30 years. ${ }^{89}$ Many other governments, following the United States' lead, regulate research involving human subjects. Some states, such as California, have also adopted their own laws dealing with human experimentation..$^{90}$

While recombinant DNA research has avoided a great deal of government regulation, research with human subjects has evolved from self-regulation to robust government regulation. Why have these two areas of research taken different trajectories? One reason human subjects research has been highly regulated is that it directly impacts human rights and wellbeing. When people die or become gravely ill as a result of an experiment, the public becomes upset and laws are passed. While the risks of recombinant DNA research to laboratory workers are concrete and realistic, other risks are abstract and theoretical. The public may be less apt to react to risks that are yet to be realised. Another reason human subjects research is highly regulated is that scientists have not done a good job developing and following their own ethical standards. Laws related to research with human subjects have been passed in response to highly publicised scandals when investigators failed to follow ethical rules. ${ }^{91}$ Not surprisingly, investigators who work with human subjects often complain that regulations and rules create needless administrative work that impedes research. ${ }^{92}$

Will dual-use research become externally regulated or will self-regulation prevail? Much depends on how scientists respond to opportunities for self-regulation presented by dual-use dilemmas. If scientists take these issues seriously and develop professional codes, journal policies, institutional oversight mechanisms, educational and training programs, and other forms of self-regulation, they may be able to avoid a high degree of government oversight. If, however, scientists fail to take appropriate steps towards self-control, a high degree of external control may result. A tragic event related to dual-use research, such as transfer of a dangerous pathogen to a terrorist who uses it to develop and deploy a lethal weapon, could motivate governments to impose stronger controls on dual-

\footnotetext{
88 Jones, J. H. 1981, Bad Blood, Free Press, London.

89 Shamoo and Resnik, op. cit.

90 Ibid.

91 Ibid.

92 Gunsalus, C. K. 2004, 'The nanny state meets the inner lawyer: overregulating while underprotecting human participants in research', Ethics and Behavior, vol. 14, pp. 369-82.
} 
use research. Hopefully, scientists will be motivated to take appropriate steps towards self-regulation before an incident occurs that compels governments to impose extensive restrictions.

\section{Acknowledgments}

This research was sponsored by the National Institute of Environmental Health Sciences (NIEHS), National Institutes of Health (NIH). It does not represent the views of the NIEHS, NIH or US Government. 